Notes

\title{
SHALL WEIGH YOUR GOD AND YOU: ASSESSING THE IMPERIALISTIC IMPLICATIONS OF THE INTERNATIONAL RELIGIOUS FREEDOM ACT IN MUSLIM COUNTRIES
}

\author{
MATTHEW L. FORE
}

\section{INTRODUCTION}

"Why do they hate us?" is a question that Americans have been asking themselves in the post-September 11 world. ${ }^{1}$ As the United States attempts to implement a new law involving international religious freedom, some members of the Muslim faith community may have yet another reason to "hate us." Some Muslims believe that they must adjudge the United States's religious imperialist instincts ("weigh your God and you") ${ }^{2}$ as the United States attempts to export

Copyright () 2002 by Matthew L. Fore.

1. See John F. Harris \& Mike Allen, President Details Global War on Terrorists and Supporters; Bush Tells Nations to Take Sides as N.Y. Toll Climbs Past 6,000, WASH. PosT, Sept. 21, 2001, at A1 (quoting President George W. Bush as stating that "Americans are asking: Why do they hate us?").

2. Rudyard Kipling, The White Man's Burden, 12 MCCLurE's MAG. 290, 291 (1899). The phrase "weigh your God and you" is a line from the poem. The poem states: "Take up the White Man's burden - / Ye dare not stoop to less_- / Nor call too loud on Freedom / To cloak your weariness. / By all ye will or whisper, / By all ye leave or do, / The silent sullen peoples / Shall weigh your God and you." Id. (emphasis added). The poem celebrates imperialism and was first published in the United States when Americans were debating the merits of imperialism. Leonard M. Baynes, An Investigation of the Alleged "White Man's Burden" in the Implementation of an Affirmative Action Program in Telecommunications Ownership, 30 RUTGERS L.J. 731, 734 n.12 (1999). The phrase "Shall weigh your God and you" emphasizes the connection between imperialism and religion. It reminds readers how imperialists often believe they should "enlighten" the conquered with the imperialists' religion, and the subjugated peoples have to "weigh your God and you" whether to accept the new religion that is being forced upon them. Kipling believed in the need to "enlighten" the conquered people on the merits of British morality and religion. His "racist" view of the conquered people is illustrated, as one critic had 
its values on religious freedom to the rest of the world. The International Religious Freedom Act of $1998^{3}$ (IRFA) may be another example that demonstrates a pattern of American imperialism to Muslims. ${ }^{4}$ IRFA's intended purpose is " $[\mathrm{t}] \mathrm{o}$ condemn violations of religious freedom, and to promote, and to assist other governments in the promotion of, the fundamental right to freedom of religion." empowers the U.S. Department of State (the State Department) and the Commission on International Religious Freedom to assess the status of religious persecution in other countries ${ }^{6}$ and dole out varying punishments based on the degree to which countries repress religious freedom.

Abroad, IRFA has been heavily criticized, ${ }^{8}$ as commentators ask: "How do you get off being the morality cop on issues that are inter-

noted, by the description of the conquered people in Kipling's poem as "wild, sullen, slothful, and heathen" as they resisted efforts to "improve them,' clinging to the familiar bondage under Pharaoh rather than striking out with Moses towards the promised land." DAVID GILMOUR, THE LONG RECESSIONAL: THE IMPERIAL LIFE OF RUDYARD KIPLING 126-29 (2002).

3. 22 U.S.C. $\$ \S 6401-6481$ (2000).

4. For purposes of this Note, the term "imperialism" refers to the domination of a country or region's culture, religion, politics, or economy by another country or region. In modern times, the United States has been accused of dominating other countries in a way similar to European domination in the colonial period. Many authors have continued to use the terms "imperialism" or "neoimperialism" to describe the recent domination of the West over the rest of the world. See, e.g., Nora V. Demleitner, Combating Legal Ethnocentrism: Comparative Law Sets Boundaries, 31 ARIZ. ST. L.J. 737, 757 (1999) ("Some non-Western countries have responded to the claim of the existence of universal human rights with a charge of imperialism since they perceive some, usually Western, countries as attempting to impose their legal systems on others."); Ann Elizabeth Mayer, Conundrums in Constitutionalism: Islamic Monarchies in an Era of Transition, 1 UCLA J. ISLAMIC \& NEAR E. L. 183, 187 n.9 (2002) (describing Muslim attempts to block "Western cultural imperialism"); Makau Mutua, Terrorism and Human Rights: Power, Culture, and Subordination, 8 BufF. Hum. RTS. L. REV. 1, 4 (2002) (noting that the West uses "[p]olitical imperialism-defined today as global American leadership" as "an indispensable paradigm in the ordering of the relationship between Europeans and non-European peoples"); Kevin Mark Smith, The United Nations Convention on the Rights of the Child: The Sacrifice of American Children on the Altar of Third-World Activism, 38 WASHBURN L.J. 111, 144 (1998) (stating that what the West views as charitable behavior, "'developing countries have come to define as imperialistic, self-serving, and a return to a form of colonialism in which whites exploit and steal natural resources"' (quoting Mary C. Hester, Intercountry Adoption from a Louisiana Perspective, 53 LA. L. REV. 1271, 1279 (1993))); Leti Volpp, Talking "Culture": Gender, Race, Nation, and the Politics of Multiculturalism, 96 COLUM. L. REV. 1573, 1602 (1996) (outlining how some scholars have justified Western imperialism).

5. 22 U.S.C. $\$ 6401(b)(1)$.

6. Id. § 6412 .

7. Id. $\S 6441-6442$.

8. Secular countries with poor religious freedom practices such as China, Vietnam, and Myanmar have all condemned IRFA as a means for the United States to meddle in other countries' affairs. See Chinese Officials Attack Report, TIMES UnION (Albany, N.Y.), Sept. 10, 2000, 
nal, domestic issues?"” In particular, some Muslims have been outspoken critics of IRFA, alleging that it seeks to supplant Islamic beliefs with American values on religious freedom. ${ }^{10}$ Because Muslim countries are some of the worst violators of religious freedom in the world today, they receive the bulk of the criticism from IRFA's monitoring entities. ${ }^{11}$

At a time when Muslim terrorists are willing to kill Americans partly to challenge the United States's hegemony, U.S. actions that are receiving condemnation for their imperialistic tendencies should

at A14 (quoting Foreign Ministry spokesman Sun Yuxi as stating that "[t]hrough fabrication and twisting facts, this report attacks China's religious policy and freedom"); Myanmar Rejects US Charge of Religious Intolerance, AGENCE FR.-PRESSE, Aug. 8, 2000 (quoting the foreign ministry as stating that "[t]he US Commission's characterization of the ... country as a land lacking in religious freedom is a misrepresentation of the highest degree and the Myanmar government completely refutes the allegation"); Vietnam Rages over US Recommendation to Block World Bank, IMF Loans, AGENCE FR.-PRESSE, Apr. 10, 2001 (quoting ministry spokeswoman Phan Thuy Thanh as stating that "[n]o country or society is entitled to meddle in the internal affairs of other nations or other societies").

9. Jane Lampman, In the Diplomatic Hot Seat-Religion, Christian SCI. Monitor, Apr. 8,1999 , at 17 .

10. Some of the strongest criticism of the Act has come from predominantly Muslim countries. When investigative bodies created by IRFA visited Egypt in March of 2001, some Egyptians reacted bitterly to what they viewed to be American meddling. Mounir Fakhry Abdel Nour, an opposition leader in parliament, stated: "Yes, we live in a world where the U.S. is the mega-power, the only power on this planet, but I am not sure the U.S. should [be] or is the judge of the moral standards and ethics in this world." Michael Slackman, U.S. Panel's Visit Riles Egyptians Rights: Muslims and Coptic Christians Say Tensions Between Them Are an Internal Matter, Not the Domain of the Religious Freedom Commission, L.A. TIMES, Mar. 21, 2001, at A11 (alteration in original). Hisham Kassem, chairman of the Egyptian Organization for Human Rights, worried over Muslim reaction to U.S. investigations, asked, "Is it in line with Christian faith to behave like a bull in a china shop and jeopardize the well-being of Christians in Egypt?" Kees Hulsman, Religious Freedom Delegation Gets Cold Shoulder, CHRISTIANITY TODAY, May 21, 2001, at 28, 28. In discussing the United States's recent focus on religious freedom, a representative of the Middle East Council of Churches in Beirut stated "that American religious activism evokes 'memories of the Crusades' and is seen in this region as 'a new invasion of American foreign policy ... [of] evangelical groups who want to convert Muslims.'” William Martin, The Christian Right and American Foreign Policy, ForEIGN POL'Y, Spring 1999, at 66,67 (alteration in original).

Scholars have also noted that there are concerns with IRFA's imperialistic tendencies. See Lampman, supra note 9, at 17 (noting that some critics see IRFA as "a bid to "make sure the mission fields are kept open" "and that "[o]thers see it as an infringement on their sovereignty, and others as another manifestation of US cultural imperialism"); Winnifred Fallers Sullivan, Exporting Religion: Where the Religious Freedom Act Fails, CommonweAL, Feb. 26, 1999, at 10,11 (questioning whether, in supporting religious freedom through IRFA, the United States is "relying on a stripped-down understanding of religion that finds its origin in Protestant and Enlightenment theories of the state and of religion ... which often simply refuses to acknowledge cultural aspects of religious life").

11. See infra Part II.A. 
be reexamined to assess whether there is any merit to the imperialist critique. Accordingly, this Note assesses the extent to which the United States's attempt to foster religious freedom through IRFA is an act of imperialism. The Note concludes that though IRFA has some preventable flaws, it is not an act of imperialism, and the United States must act through IRFA to further religious freedom because of the abysmal status of religious freedom in the world today.

The Note contains four Parts. Part I outlines how the United States developed a commitment to international religious freedom. It details why it is important to defend international freedom and explains what IRFA's purpose is, how it came to be enacted, and how it currently functions. Part II expands on international concerns with IRFA. It surveys the conflicts between the United States and Muslim countries regarding religious freedom and articulates the charges of imperialism that critics generally make against IRFA. Part III rebuts the claim that IRFA is an act of imperialism. It outlines how IRFA is designed to reinforce international treaties; it articulates how IRFA supports religious freedom as a universal right; it dismisses the claim that IRFA requires a separation of church and state; and it addresses the possibility that religion is being used as a pretext for misdeeds. Part IV recommends what changes are needed to rectify flaws in IRFA. It highlights the problems of IRFA being too Christianfocused, criticizes IRFA for failing to require a self-assessment of the United States, argues that the United States has failed to support existing international frameworks that champion all human rights, and notes the implications of the U.S. political actors having too much flexibility under IRFA to decide which countries warrant censure.

\section{THE UNITED STATES'S COMMITMENT TO INTERNATIONAL RELIGIOUS FREEDOM}

\section{A. Why Defense of Religious Freedom is Critical for the United States}

International religious freedom should be an important concern for the United States. Beyond any interests specific to the United States, religious freedom in the world is in a calamitous state. Currently, "[m]ore than one-half of the world's population lives under regimes that severely restrict or prohibit the freedom of their citizens to study, believe, observe, and freely practice the religious faith of 
their choice." ${ }^{12}$ Religious minorities currently suffer under an onslaught of persecutions including rape, imprisonment, and murder. ${ }^{13}$ In the aftermath of the cold war, there has been "a system-wide shift in the ideational underpinning of conflict from militant secular ideologies to highly virulent and exclusivist assertions of religious or ethnic identity." $" 14$

More specific to the United States, the religiously motivated attacks of September 11 should notify all American international scholars and policymakers that the status of religion in other countries does affect American interests. More specifically, religious freedom has a direct effect on American interests because American security and protection of human rights are now aligned. Analysts have begun to recognize a link between terrorism and religious suppression, finding that if a country has a tendency to oppress religious minorities, it is also more likely to harbor and produce terrorists. ${ }^{15}$ As one scholar has stated: "We need to remember that failure to respect legitimate claims for religious freedom can itself become a source of political instability and terrorism."16 Ensuring "religious liberty would, among other things ... moderate fundamentalist and nationalist movements by removing some of the impetus to their organization and terror." ${ }^{, 17}$ Practitioners have also addressed the link between a lack of religious freedom and terror. Paula Dobriansky, undersecretary of state for global affairs stated: "[Terrorism] includes a willingness to view other human beings as objects to be destroyed. It is at its core a pure form of anti-religion. At its best, religion is, therefore, an

12. 22 U.S.C. $\$$ 6401(a)(4) .

13. See infra Part II.A.

14. H. Victor Conde, Protection of Religious Freedoms Under International Humanitarian Law and International Human Rights Law in Times of Armed Conflict, 5 U.C. DAVIS J. INT'L L. \& POL'Y 95, 96 (1999).

15. See Raju Chebium, U.S. Should Promote Religious Diversity to Win Terrorism War, Advocates Say, GANNETT NewS SERV. Dec. 4, 2001 (quoting Tamara Sonn, an Islam expert, as stating that "[t]here is a connection between religious intolerance and terrorism in the Muslim world"); Duncan Moon, NPR News (National Public Radio broadcast, May 7, 2002) (quoting the chairman of the U.S. Commission on International Religious Freedom as stating that " $[\mathrm{t}]$ errorism finds a happy breeding ground in part because people feel disenfranchised and oppressed").

16. Gordon H. Smith, Religious Freedom and the Challenge of Terrorism, 2002 BYU L. REV. 205, 214.

17. Nathan A. Adams IV, A Human Rights Imperative: Extending Religious Liberty Beyond the Border, 33 CORNELL INT'L L.J. 1, 64 (2000). 
antidote to fanaticism, not its cause." ${ }^{18}$ She further added that countries that harbor terrorists fail to "give an adequate voice to a broad spectrum of religions." ${ }^{19}$ Similarly, as expressed by Michael Young, the chairman of the U.S. Commission on International Religious Freedom, expanding religious freedom is itself a key tool in the war on terrorism. ${ }^{20}$

\section{B. Congressional Response through IRFA}

1. Enactment of IRFA. Though religious freedom has been called the "orphan child" of all the human rights prerogatives, ${ }^{21}$ that sentiment slowly began to change in the 1990s as Americans became more aware of worldwide religious persecution. ${ }^{22}$ In Congress, advocates who were concerned with the status of religious freedom began demanding a bill that would seek to protect religious groups who were persecuted abroad. ${ }^{23}$ In May of 1997, Republican Representative Frank Wolf of Virginia introduced a bill, which was championed by conservative Christian groups, ${ }^{24}$ that was designed to impose "sanctions against countries engaged in a pattern of religious persecution." ${ }^{25}$ However, the Clinton White House initially opposed the legislation because it was alarmed that early versions of the law demanded automatic sanctions when any country was found to have

18. Lee Davidson, Allies' Stand on Religion Questioned, DESERET News (Salt Lake City, Utah), Nov. 27, 2001, at A1.

19. Id.

20. See id. (noting that the war on terrorism and the championing of religious liberties are not mutually exclusive goals).

21. Review \& Outlook: Keeping the Faith, WALL ST. J., Oct. 13, 2000, at W15 (quoting Paul Marshall, the editor of Freedom House's report of world religious freedom).

22. See Larry Witham, Religious-Liberty Envoy Aims for Reconciliation Above All: Ambassador-Level Appointee Pursues Quiet Diplomacy, WASH. TIMES, Nov. 5, 1999, at A2 ("The new focus on religious liberty results from a push that began in 1995, when global persecution of Christians was held out as a human rights issue comparable to the Soviet Union's retention of Jewish refuseniks in the 1980s.").

23. See id. ("In early 1996, evangelical Christians and some Catholics and Jews assembled in Washington to call on the Clinton administration to do something, and lobbied Capitol Hill to draft the appropriate laws.").

24. See Sean D. Murphy, Contemporary Practice of the United States Relating to International Law, 93 AM. J. INT'L L. 470, 480 (1999) (stating that “the proposed law was strongly endorsed by the Christian Coalition and other conservative religious groups in the United States").

25. T. Jeremy Gunn, A Preliminary Response to Criticisms of the International Religious Freedom Act of 1998, 2000 BYU L. REV. 841, 843 (quoting H.R. 1685, 105th Cong. (1997); S. 772, 105th Cong. (1997)). 
violated religious freedom. ${ }^{26}$ Eventually, compromise legislation emerged and the final version of the bill, which came to be known as the International Religious Freedom Act of 1998, had more robust waiver provisions that enabled the president to decide whether matters such as "important national interests" were more important than curtailing religious freedoms. ${ }^{27}$ Both houses of Congress passed the bill unanimously, and President Clinton signed it into law in October of $1998 .^{28}$

The law makes religious freedom a "central element of U.S. foreign policy," as President Clinton declared when signing the bill into law. ${ }^{29}$ It created an official U.S. policy of "[s]tanding for liberty and standing with the persecuted, to use and implement appropriate tools in the United States foreign policy apparatus, including diplomatic, political, commercial, charitable, educational, and cultural channels, to promote respect for religious freedom by all governments and peoples." ${ }^{30}$

2. Implementation of IRFA. IRFA essentially has three provisions that are relevant to this Note. First, IRFA created the Office of International Religious Freedom in the State Department ${ }^{31}$ and charged it with creating an Annual Report on Religious Persecution ${ }^{32}$ to detail violations of religious freedom and to outline potential courses of action for the United States to take. ${ }^{33}$ The Report has two components: one describing U.S. actions that have impacted religious freedom, and another summarizing what other countries have done to foster or impede religious freedom. ${ }^{34}$ The State Department uses the Report to identify "particularly severe" violators of religious free-

26. Justus R. Weiner, Human Rights Trends in the Emerging Palestinian State: Problems Encountered by Muslim Converts to Christianity, 8 MSU-DCL J. INT'L L. 539, 579 (1999).

27. U.S. Acts to Combat Religious Persecution, AsIAN WALl ST. J., Oct. 12, 1998, at J9.

28. Robert Seiple, Religious Liberty: How Are We Doing?, Christianity TODAY, Oct. 22, 2001 , at $98,98$.

29. William J. Clinton, Statement on Signing the International Religious Freedom Act of 1998 (Oct. 27, 1998), in 34 WKLy. Compilation Presidential Documents 2149, 2149 (1998).

30. 22 U.S.C. $\$$ 6401(b)(5) (2000).

31. Id. $\$ 6411(\mathrm{a})$.

32. Id. $\S 6412(\mathrm{~b})$.

33. Id. $\$ 6441(\mathrm{a})(1)(\mathrm{B})$; Senator Orrin G. Hatch, Religious Liberty at Home and Abroad: Reflections on Protecting this Fundamental Freedom, 2001 BYU L. REV. 413, 418-19.

34. 22 U.S.C. $\$ 6412(b)$. 
dom. ${ }^{35}$ The Act also created an Ambassador at-large who focuses on religious persecution. ${ }^{36}$

Second, the Act established a Commission on International Religious Freedom ${ }^{37}$ to review violations of religious freedom ${ }^{38}$ and make policy recommendations to the president and Congress. ${ }^{39}$ Members serve two-year terms and are appointed by the House, the Senate, and the president. ${ }^{40}$ The Commission analyzes the reports released by the State Department and provides policy recommendations. ${ }^{41}$ The Commission also issues its own reports on religious freedom setting forth its recommendations for concerns involving religious freedom. ${ }^{42}$

Third, the Act allows for presidential actions if countries violate religious freedom. ${ }^{43}$ The president has varying alternatives, depending on whether the State Department has characterized the offending country as one that engages in violations of religious freedom or as a country that has engaged in "particularly severe violations," meaning "systematic, ongoing, egregious violations of religious freedom," including torture, prolonged detention or "other flagrant denial of the right to life, liberty, or the security of persons." ${ }^{, 44}$ For the more egregious offenses, the president can choose from several economic options such as ending development assistance, banning Export-Import Bank loans, or prohibiting U.S. government purchases from the foreign government. ${ }^{45}$ IRFA gives the president considerable flexibility in deciding whether to impose sanctions. ${ }^{46}$ If there is an "important

\footnotetext{
35. Id. $\S 6412(\mathrm{~b})(1)(\mathrm{A})(\mathrm{iii})$.

36. Id. $\S 6411$ (a). "The Ambassador's role is to advance the right to religious freedom abroad, denounce violations of that right, and recommend appropriate policies and responses to the U.S. government, specifically the President and Secretary of State, when he finds religious rights are violated." Christy Cutbill McCormick, Comment, Exporting the First Amendment: America's Response to Religious Persecution Abroad, 4 J. INT'L LEGAL STUD. 283, 324 (1998).

37. 22 U.S.C. $\$ 6431$.

38. Id. § 6432(a)(1).

39. Id. $\S 6432(\mathrm{a})(2)$.

40. Id. $\S 6431(\mathrm{~b})-(\mathrm{c})$.

41. Id. \$6432; Nichol Jeanette Starr, Who Asked You?: The Appropriateness of U.S. Leadership in Promoting Religious Freedom Worldwide, 33 VAND. J. TranSNAT'L L. 987, 1004 (2000).

42. 22 U.S.C. § 6433(a).

43. Id. § 6441-6461.

44. Id. § 6402(11).

45. William M. McGlone \& Timothy P. Trenkle, Economic Sanctions and Export Controls, 33 INT'L LAW. 257, 266 (1999).

46. McCormick, supra note 36, at 325.
} 
national interest" concern, the president can waive the sanctions. ${ }^{47}$ For less serious offenses, the president can choose to offer a private demarche or to declare a public condemnation. ${ }^{48}$

Since the passage of IRFA, the president, the State Department, and the Commission have all acted to protect religious freedom by following provisions of IRFA. For example, the State Department has issued an annual report on the status of religious freedom. ${ }^{49}$ Its Report issued in 2001 included an analysis of 195 countries and outlined "Barriers to International Religious Freedom," "Positive Developments in the Area of Religious Freedom,", and "U.S. Action to Promote International Religious Freedom." ${ }^{52}$ The Commission has also been actively evaluating the status of religious freedom. For example, on August 16, 2001, it sent a letter to Secretary of State Colin Powell urging the State Department to name Burma, China, Iran, Iraq, Laos, North Korea, Saudi Arabia, Sudan, and Turkmenistan as countries of particular concern. ${ }^{53}$ The president has used his powers under IRFA to sanction countries found to be in violation of the Act. For example, President Clinton relied on IRFA's mandate when he banned U.S. exports of crime-fighting equipment to China for two years. $^{54}$

\section{UNDERSTANDING INTERNATIONAL CONCERN WITH IRFA}

The United States's awakening to the problems of international religious freedom has not gone unnoticed by other countries. In particular, Muslim countries have charged the United States with imperialistically meddling in the affairs of sovereign states.

47. 22 U.S.C. $\$ 6447(a)(3)$.

48. Hatch, supra note 33 , at 418-19.

49. U.S. DEP'T OF STATE, 2001 ANNUAL REPORT ON INTERNATIONAL RELIGIOUS FREEDOM (Comm. Print 2001).

50. Id. at xvi.

51. Id. at xxiv.

52. Id. at xxvii.

53. U.S. COMM'N ON INT'L Religious FREedom, ANNUAl REPORT OF THE UNited STATES COMMISSION ON INTERNATIONAL RELIGIOUS FREEDOM 4-5 (2002).

54. China Blasts U.S. Criticism, Sanctions, DESERET News (Salt Lake City, Utah), Dec. 7, 1999, at A13. 


\section{A. IRFA's Focus on Muslim Countries}

In the modern era, Muslim countries have been particularly egregious violators of religious freedom. ${ }^{55}$ The U.S. Commission on International Religious Freedom has assessed foreign countries to spotlight the "most egregious violators" of religious freedom. ${ }^{56}$ It found that nine countries violated religious freedom so severely that they should be designated "countries of particular concern." those nine, five countries-Sudan, Turkmenistan, Iran, Iraq, and Saudi Arabia - are all countries with a large Muslim populace. A tenth Muslim country, Afghanistan, while under the Taliban regime, was designated "a particularly severe violator of religious freedom." 58

These countries garnered significant attention from IRFA's monitoring agencies for good reason. In Afghanistan, under the Taliban regime, the government continually repressed religious minorities, forbade non-Muslim minorities from worshipping, and destroyed two historic Buddhist statues because they reflected non-Muslim beliefs. ${ }^{59}$ Religious persecution in Sudan "is intertwined with ... deliberate denial of humanitarian assistance, abduction of women and children into conditions of slavery, and the forcible displacement of populations from oil-producing areas." "Members of unrecognized religious communities" in Turkmenistan "have reportedly been arrested, detained[,] ... imprisoned, deported, harassed, [and] fined.",61 Iran allows "egregious violations of religious freedom, including prolonged detention and executions based primarily or entirely upon the

55. The purpose of this analysis is not intended in any way to disparage Muslim peoples or the practice of Islam. Although it is true that many Muslim countries have poor religious freedom records now, one should not conclude that the practice of Islam correlates to a tendency for suppression of religion more so than any other religion in the long run. In fact, Bernard Lewis, an esteemed Islamic historian, has stated that "for much of history religious minorities did better under Muslim rulers than they did under Christian ones." Fareed Zakaria, The Politics of Rage: Why Do They Hate Us?, NEWSWEEK, Oct. 15, 2001, at 22; see also Edna BoyleLewicki, Need World's Collide: The Hudad Crimes of Islamic Law and International Human Rights, 13 N.Y. INT'L L. REV. 43, 57 (2000) (“Certain religions such as Judaism, Christianity, and Zoroastrianism were accorded better treatment within Islamic societies than extended to non-Christians in medieval Europe."); Ann Elizabeth Mayer, Islam and the State, 12 CARDOZO L. REV. 1015, 1024 (1991) ("The record of Islam's tolerance of non-Muslim minorities compares very favorably with the treatment of non-Christian minorities in the West.").

56. U.S. COMM'N ON INT'L RELIGIOUS FREEDOM, supra note 53, at 25.

57. Id.

58. $I d$.

59. U.S. DEP'T OF STATE, supra note 49, at 498-503.

60. U.S. COMM'N ON INT'L RELIGIOUS FREEDOM, supra note 53, at 58.

61. Id. at 27. 
religion of the victims." ${ }^{62}$ Iraq conducts "a brutal campaign of murder, summary execution, arbitrary arrest, and protracted detention against the Shi'a religious leaders and adherents." ${ }^{, 3}$ Saudi Arabia "denies religious freedom.... Numerous Christians and Shi'a Muslims continue to be detained, imprisoned, and deported." ${ }^{64}$

\section{B. The Critics' Argument for Why IRFA is Imperialistic}

1. IRFA Exports American Concepts of Religious Freedom. The imperialist charges against IRFA are based on the belief that by choosing to implement IRFA, the United States is establishing a policy that conflicts with the teachings and practices of the Muslim faith community. ${ }^{65}$ Critics claim that IRFA seeks to instill a climate of religious freedom that is a particularly Americanized version of religious freedom that has been developed over the course of its history. ${ }^{66}$ For example, one critic of IRFA has stated that the act "is clearly not intended to promote freedom of religion. It is intended to promote freedom of a certain kind of religion, religion as it has been shaped by American law and history, religion that has been set apart and contained by the secular state."

Some critics of IRFA embrace a relativist view of human rights in which the world consists of conflicting units of culture that collide

62. Id. at 9 .

63. U.S. DEP'T OF STATE, supra note 49, at xviii.

64. U.S. COMM'N ON INT'L RELIGIOUS FREEDOM, supra note 53, at 12.

65. See Religious Freedom Act Gets Wide Acclaim, 115 Christian CENTURy 1015, 1016 (1998) (noting that though the bill "sat well with the National Council of Churches [(NCC)]," NCC General Secretary Joan Brown Campbell "cautioned against the U.S.'s acting 'as the religious police of the world" and "urged the U.S. not to impose its brand of religious freedom on cultures that view the matter in a different light, as do many Muslim countries").

66. See Gunn, supra note 25, at 845 (noting criticism that IRFA promotes an American notion of disestablishment that is "anathema" to some Muslim countries). Some aspects of IRFA support the view that IRFA is wedded to an Americanized version of religious freedom. The Ambassador-at-large's interpretation of IRFA recognizes that "the tone draws deeply from the American experience: 'Many of our Nation's founders fled religious persecution abroad, cherishing in their hearts and minds the ideal of religious freedom. They established in law, as a fundamental right and as a pillar of our nation, the right to freedom of religion."' Seiple, supra note 28, at 98 (quoting 22 U.S.C. § 6401(a)(1) (2000)). The language of IRFA also supports the criticism that "it is based narrowly on the American historical experience." Gunn, supra note 25, at 845 .

67. Sullivan, supra note 10 , at 11 . 
with one another. ${ }^{68}$ These cultural units are all influenced by their own religious and cultural traditions. ${ }^{69}$ This relativist lens implies that when conflict occurs between these distinct cultural units, the resulting imposition of one unit's cultural values over another's is an act of imperialism; it is not an act of fostering universal rights. In other words, so the argument goes, what the United States suggests to be "universal" religious rights are really Western values cast in a way to appear neutral.

One imperialistic tendency of IRFA, according to critics, is that IRFA seeks to foster an Americanized system in which the church and state are kept separate. ${ }^{70}$ By doing so, IRFA intrudes upon Muslim values because in much of the Muslim world, the Qur'an or Islamic law must control sovereign laws. For these countries, the Qur'an and Islamic law controls how a Muslim must act toward others, including instructing how the government must act towards the population. ${ }^{71}$

68. See Samuel P. Huntington, The Clash of Civilizations?, in GlobAlizATION AND THE Challenges of A New Century: A Reader 3 (Patrick O'Meara et al. eds., 2000) (arguing that in the modern world, the sources of conflict will be based on cultural divisions rather than on ideology or economic forces); David Little, Does the Human Right to Freedom of Conscience, Religion, and Belief Have Special Status?, 2001 BYU L. REV. 603, 604 (explaining that religious freedom is the subject of "intense international debate" over cultural relativism).

69. See Little, supra note 68 , at 604 (observing that relativists assume that "notions of human rights, including rights to religious freedom, vary according to culture and tradition").

70. One critic explains:

[W] have not revised our peculiarly modern and American understanding of religion. In promoting religious freedom we are still relying on a stripped-down understanding of religion that finds its origin in Protestant and Enlightenment theories of the state and of religion-one that sees religion's role as one of teaching virtue to its citizens through the training of private consciences-and which often simply refuses to acknowledge cultural aspects of religious life.

Sullivan, supra note 10, at 11.

71. See Akhtar Khalid Bhatti \& Gul-e-Jannat, The Holy Quran on Human RIGHTS iii (1996) (clarifying that the law gives directions on how to act toward one's fellow human being, and "these directions also include the functions and responsibilities of State towards its population"); Purva Desphande, Note, The Role of Women in Two Islamic Fundamentalist Countries: Afghanistan and Saudi Arabia, 22 WOMEN's RTS. L. REP. 193, 193 (2001) ("In many Islamic countries the [Qur'an] . . lays down the foundation for not just the law, but for a way of life."); M.H.A. Reisman, Comment, Some Reflections on Human Rights and Clerical Claims to Political Power, 19 YALE J. INT'L L. 509, 511 (1994):

Islam views life in its totality and purports to provide guidance for every aspect of human life. It recognizes no divisions among the spiritual, social, economic, and political sectors of life. No aspect of life is any less important to enhancing the worship of God. Islam thus cannot leave outside its domain the affairs of the state and the exercise of official power. 
As an example of how Islamic control of human rights laws can lead to conflict with IRFA and other human rights initiatives, consider the 1990 Cairo Declaration for Human Rights. ${ }^{72}$ Muslim human rights activists created the Cairo Declaration as a means to foster human rights in Muslim countries. ${ }^{73}$ Islamic religious law, often called "Sharîa," permeates the Declaration, and is designed to serve as a virtual "gap-filler" for the document. For example, Article 24 states that "“[a]ll the rights and freedoms stipulated in this Declaration are subject to the Islamic [Sharîa]'-without any attempt at defining what limits the [Sharîa] would entail." 75 Though the Cairo Declaration seems to align with IRFA's intent to protect human rights, the reliance on Islamic law can cause conflict between IRFA's goals and the Cairo Declaration. For example, Article 10 of the Declaration draws from the Qur'an and includes the provision: "It is prohibited to exercise any form of compulsion on man or to exploit his poverty or ignorance in order to convert him to another religion or to atheism." ${ }^{76} \mathrm{Al}-$ though this provision sounds promising, when read in conjunction with Article 24, it becomes clear that "Article 10 prevents the use of compulsion or exploitation to convert someone from Islam to another religion or atheism, not vice versa." 77 The Declaration fails to mention what the particular rights of non-Muslims are in regard to conversion. ${ }^{78}$

72. Cairo Declaration on Human Rights in Islam, Aug. 5, 1990, reprinted in BASIC DoCUMENTS ON HUMAN Rights 764-69 (Ian Brownlie \& Guy S. Goodwin-Gill, eds., 2002).

73. See Adams, supra note 17, at 58 (noting the general lack of such instruments in that region, and describing the Declaration as a "more visible" measure).

74. "Sharîa," also spelled "Shari'ah" or "Sharia," is the religious law of Islam:

[T]he [S]haria is generally defined as the concept of having no separation between the rule of government and the law of God. As one author has put it, "In principle this remarkably comprehensive scheme allows no ultimate distinction between religion and morality, law and ethics. All are seen as proceeding directly from the command of God, though there is room for humans to argue about the details."

Lance S. Lehnhof, Note \& Comment, Freedom of Religious Association: The Right of Religious Organizations to Obtain Legal Entity Status Under the European Convention, 2002 BYU L. ReV. 561, 575 n.59 (quoting Malise RuthVEN, Islam: A Very SHORT INTROduction 86 (1997)).

75. Ann Elizabeth Mayer, Universal Versus Islamic Human Rights: A Clash of Cultures or a Clash with a Construct?, 15 MiCH. J. INT'L L. 307, 329 (1994) (quoting Cairo Declaration on Human Rights in Islam, supra note 72, art. 24).

76. Cairo Declaration on Human Rights in Islam, supra note 72, at 766.

77. Adams, supra note 17, at 59 .

78. See id. (noting that the Declaration "does not expressly reference the rights of nonMuslims and noticeably fails to provide for 'freedom of thought, conscience and religion,' unlike the U.N. international human rights instruments"). 
Other examples exist where human rights initiatives such as IRFA are directly contrary to Islamic teachings. A primary source of conflict between the implementation of IRFA and Muslim beliefs involves the problem of apostasy. One Islamic proponent has stated that "Islam does not tolerate apostasy, as the adoption of Islam is not imposed by force, consequently the subsequent renunciation of Islam is inconceivable. Such acts of apostasy are seen by some as high treason worthy of capital punishment." who repudiates his faith in Islam, whether directly or indirectly, is guilty of a capital offense punishable by death." ${ }^{, 0}$ Several Muslim states have enacted apostasy laws. Sudan's Islamic legal code, based on the Sharîa, includes the death penalty for "any Muslim who advocates the rejection of Islamic beliefs or announces his own rejection of Islam by word or act." Similarly, Pakistani blasphemy laws involve the death penalty for anyone who blasphemes Mohammed. ${ }^{82}$ Muslim critics see no ways in which to reconcile the goals of IRFA and the principles behind these Sharîa laws. One scholar has noted that "some interpretations of [Sharîa] law pit Islam against the principle of the primacy of international law." ${ }^{, 3}$

2. IRFA Intrudes upon a Sovereign Core. Religion has played a unique and predominant role in the impulse toward nationhood, ${ }^{84}$ and to intervene in a country's handling of its religious practices is to infringe upon a fundamental sovereign power. ${ }^{85}$ For this reason, a coun-

79. Muhammad Tal'at Al-Ghunaimi, Justice and Human Rights in Islam, in JUSTICE AND HUMAN RigHTS IN ISLAMIC LAW 1, 10 (Gerald E. Lampe ed., 1997).

80. Abdullahi Ahmed An-Na'im, Human Rights in the Muslim World: Socio-Political Conditions and Scriptural Imperatives: A Preliminary Inquiry, 3 HARV. HUM. RTS. J. 13, 23 (1990).

81. Ann Elizabeth Mayer, The Fundamentalist Impact in Iran, Pakistan, and the Sudan, in Fundamentalisms And the STATE 110, 141 (Martin E. Marty \& R. Scott Appleby eds., 1993) (citing Sudan: New Islamic Penal Code Violates Basic Human Rights, NeWS FrOM AFRICA WATCH, Apr. 9, 1991, at 1,7).

82. Said Amir Arjomand, Religious Human Rights and the Principle of Legal Pluralism in the Middle East, in Religious Human Rights IN Global Perspective: Legal Perspectives 331, 342 (Johan D. van der Vyver \& John Witte, Jr. eds., 1996).

83. Jane Lampman, To Be Alone with One's God, Christian SCI. Monitor, Dec. 16, 1999, at 11 (quoting FreEdom OF RELIGION AND BELIEF: A WORLD REPORT (Kevin Boyle \& Juliet Sheen eds., 1997)).

84. For example, in Islamic states, religion has played a major role in the development of nations. See Reisman, supra note 71, at 512 (explaining how "[r]eligion . . . became the cornerstone of many nationalistic and other political movements in the Islamic world").

85. Religious determination is an essential aspect of sovereignty because the concept of sovereignty arose as a result of Europe's religious wars which ended with an agreement that rulers were allowed to control the religion within their borders. "In modern history, the principle 
try's administration of religious freedom has been given a distinct place in the human rights pyramid of values. ${ }^{86}$ Whereas there has been an outpouring of support over the past fifty years for restrictions on human rights issues such as freedom from torture or slavery, freedom of religion has not been met with a uniformity of response in the human rights community. ${ }^{87}$ What makes religion a unique aspect of a country's sovereign powers? History and culture both play an essential role.

Historical connections between religion and sovereignty make any attempt to restrict sovereignty for the cause of religious freedom difficult. Countries do not generally form to exercise their right to torture or restrict free speech; however, countries do form based partly on a desire to dictate the country's religion. ${ }^{88}$ Historically, religion has been a catalyst to the formation of sovereign states. "[T]here is a strong impulse on the part of state authorities to ally themselves with one, often a majority, ethnoreligious group so as to create a national faith considered essential for political identity." current borders are the result of a historical rallying around a particular religion. Israel, of course, is the most obvious example of religion driving the movement toward sovereignty. Other examples abound. Different Muslim sects have struggled for sovereign control

of sovereignty was established under the Treaty of Westphalia .... The principle of noninterference in the affairs of another state is viewed as a corollary of the more basic principle of sovereignty ...." T. Modibo Ocran, The Doctrine of Humanitarian Intervention in Light of Robust Peacekeeping, 25 B.C. INT'L \& COMP. L. REV. 1, 3 (2002). The Treaty of Westphalia enshrined the principle that "cuius regio, eius religio-whose the rule, his the religion." Adams, supra note 17, at 2. This principle mandated: "Each ruler in the empire would choose the religion of his realm; all his subjects would have to conform or emigrate." Douglas Laycock, Continuity and Change in the Threat to Religious Liberty: The Reformation Era and the Late Twentieth Century, 80 MinN. L. REV. 1047, 1052 (1996).

86. See Review \& Outlook: Keeping the Faith, supra note 21, at W15 (describing as persuasive the argument that "freedom of religion is important not just in itself but as a bellwether for other freedoms").

87. See Adrian Karatnycky, Human Rights Groups Ignore Today's Martyrs, WALL ST. J., Oct. 23, 1997, at A18 ("[M]ost major human rights groups have paid scant attention to the issue of religious persecution around the world.").

88. See Gunn, supra note 25 , at 845 ("As a vastly more complex issue than freedom from torture or freedom of expression, the freedom of religion and belief is necessarily intertwined with each country's particular identity, traditions, culture, and nationhood.").

89. Little, supra note 68, at 608; see also Mayer, supra note 55, at 1023 n.24 (noting the dominion of the Sunni sect over some other Muslim minority sects). 
for years. ${ }^{90}$ India and Pakistan developed partly as sovereign states as a means to protect the status of Hindus and Muslims in the region. ${ }^{91}$ The redrawing of Bosnia and Kosovo based on religion and ethnicity show that religion still plays a central role in the impetus for sovereignty.

The second reason why religion is at the core of sovereignty is because religion plays a predominant role in reinforcing a country's cultural self-identity. "[T]he freedom of religion and belief is necessarily intertwined with each country's particular identity, traditions, culture, and nationhood." "Religious histories, institutions, ideas, and people" shape a country's shared history. ${ }^{93}$ For example, Saudi Arabia's practice of Islam is imbedded in the soul of Saudi Arabia"to be a Saudi is to be a Wahhabi Muslim." As As Human Rights Watch has noted about Saudi Arabia: "In few countries in the world is the denial of religious freedom so integral to the self-conception and ethos of the government." 9.5

In Muslim countries like Saudi Arabia, Islam is such a unifying cultural force that group rights may be valued more than the individual rights so often championed in Western society. As one scholar has noted, "Islamic theory does not present a notion of the rights of the individual. Rights do not attach to men qua men.... It is more appropriate to refer to the privileges of man." "96 Accordingly, some Muslim countries may place more value on the societal group right to practice the majority faith than on the individual rights to freedom of religion. ${ }^{97}$ In this way,

90. See Carolyn Cox Cohan, International Mavericks: A Comparative Analysis of Selected Human Rights and Foreign Policy Issues in Iran and the United States, 33 GEO. WASH. INT'L L. REV. 197, 208-09 (2001) (explaining how Iran developed as a Shi'ite nation).

91. See Farooq Hassan, Religious Liberty in Pakistan: Law, Reality, and Perception (A Brief Synopsis), 2002 BYU L. REV. 283, 285 ("After two decades of failed attempts . . to unite the Hindu and Muslim communities, the 'Lahore Resolution' finally called for a separate Muslim state.").

92. Gunn, supra note 25 , at 848 .

93. Sullivan, supra note 10 , at 11 .

94. Gunn, supra note 25 , at 845 .

95. Press Release, Human Rights Watch, U.S. Report on Religious Freedom Is Flawed, (Oct. 26, 2001), http://www.hrw.org/press/2001/10/religious1026.htm (on file with the Duke Law Journal).

96. DAVid LitTle et Al., Human Rights AND the Conflict of Cultures 33 (1988) (quoting James P. Piscatori, Human Rights in Islamic Political Culture, in MORAL IMPERATIVES OF HUMAN Rights 144, 157-58 (Kenneth W. Thompson ed., 1980)).

97. See Ellis Mishulovich, Book Note, 33 STAN. J. INT’L L. 416, 419 (1997) (reviewing THE NeW World Order: SOVEREIGNTy, Human Rights AND the SElF-DETERMination of 
the right being claimed is the right to live in a community that accords with religious principles. This is considered a group right because it involves more than individual belief or action; it also takes into account the relationships between people within the society and the effect that one person's sinful actions has on others and on society as a whole. ${ }^{98}$

Thus, in some Muslim countries, the freedom of religion may include the right to create a utilitarian model in which the freedom of the majority is allowed. The majority rights are important to the Muslim faith because Islam is a public faith- "[t]he Muslim's obligation is not only a private relationship between the individual and God (familiar to Protestant Christian doctrine)[;] it also involves a communal duty. '[T]he Islamic community (ummah) is to be the dynamic vehicle for the realization of the divine pattern.", 99 Thus, though rights of minorities could perhaps be trammeled under such a model, even more rights would be restricted if Muslims had to surrender their right to live in a community where a minority's religious acts intruded upon their creation of a religious society. ${ }^{100}$

\section{REBUTTING IMPERIALISTIC ACCUSATIONS AGAINST IRFA}

Though critics have made imperialistic arguments against IRFA, most have misunderstood IRFA. IRFA does not enforce a particularized American view of religious freedom. Instead, IRFA champions universal rights, reinforces international treaties, and attempts to curtail the use of religious pretext to justify oppression.

PEOPLES (Mortimer Sellers ed., 1996) (explaining that a scholar has found that selfdetermination is "problematic within Islamic political thought because [it] challenge[s] the core principles of Islamic ethics, which promote a universal community that transcends ethnic, tribal, racial, or national distinctions")).

98. S.I. Strong, Law and Religion in Israel and Iran: How the Integration of Secular and Spiritual Laws Affects Human Rights and the Potential for Violence, 19 MICH. J. INT'L L. 109, 194 (1997).

99. Kimberly Younce Schooley, Comment, Cultural Sovereignty, Islam, and Human Rights-Toward a Communitarian Revision, 25 CUMB. L. REV. 651, 660 (1995) (quoting JoHN L. ESPOSITO, WOMEN IN MUSLIM FAMILY LAW 1 (1982)).

100. Though Americans fail to admit it, the American model may not be as different as one would like to believe. Consider polygamy in America as an example of a group right trumping an individual religious belief. See, e.g., Cleveland v. United States, 329 U.S. 14, 20 (1946) (citation omitted):

[I]t has long been held that the fact that polygamy is supported by a religious creed affords no defense in a prosecution for bigamy. Whether an act is immoral within the meaning of the statute is not to be determined by the accused's concepts of morality. Congress has provided the standard. 


\section{A. IRFA is Designed to Reinforce International Treaties}

To evaluate the claim that IRFA is not seeking to foster uniquely Western or American values, one must examine the international agreements that IRFA is designed to support. Importantly, IRFA does not draw its language from the American Constitution; instead, the language of IRFA is taken from international treaties. ${ }^{101}$ The legislative findings of IRFA ${ }^{102}$ cite to both the language of the Universal Declaration of Human Rights ${ }^{103}$ (UDHR) and the International Covenant on Civil and Political Rights (ICCP). ${ }^{104}$ The legislative findings of IRFA also note that freedom of religion is a universal human right recognized by

the Universal Declaration of Human Rights, the International Covenant on Civil and Political Rights, the Helsinki Accords, the Declaration on the Elimination of All Forms of Intolerance and Discrimination Based on Religion or Belief, the United Nations Charter, and the European Convention for the Protection of Human Rights and Fundamental Freedoms. ${ }^{105}$

The reliance on these documents is useful for rebutting the imperialistic charges against IRFA because, as the State Department has noted, by signing such documents, "[t]he vast majority of the world's governments have committed themselves to respect religious freedom."

The United Nations (UN) has long recognized the essential nature of having religious freedom as the bedrock for all of its human rights initiatives. President Franklin D. Roosevelt identified freedom of religion as one of the "four essential human freedoms" that must be included in any international instruments. ${ }^{107}$ The first major international document that called for religious freedom was the UDHR, which stated that: "[e]veryone has the right to freedom of thought, conscience and religion; this right includes freedom to change his religion or belief, and freedom, either alone or in community with others and in public or private, to manifest his religion or belief in

101. Gunn, supra note 25 , at 847.

102. 22 U.S.C. $\$ 6401(\mathrm{a})(3)(2000)$.

103. G.A. Res. 217(III)A, U.N. GAOR, 3d Sess., at 71, U.N. Doc. A/810 (1948).

104. G.A. Res. 2200, U.N. GAOR, 21st Sess., Supp. No. 16, at 52, U.N. Doc. A/6316 (1967).

105. 22 U.S.C. $\$ 6401(a)(2)$.

106. U.S. DEP'T OF STATE, supra note 49 , at xv.

107. Franklin D. Roosevelt, The Annual Message to the Congress (Jan. 6, 1941), in 9 THE Public PAPERS AND AdDresses of FrAnKLin D. RoOSEVElt: 1940, at 672 (1941). 
teaching, practice, worship and observance." ${ }^{108}$ The treaty was based on the precept that "[a]ll human beings are born free and equal in dignity and rights" and are "endowed with reason and conscience."109

Many of the countries that have been deemed the worst violators of religious freedom have signed the UDHR. ${ }^{110}$ In 1948, when the UDHR was proposed, seven out of the eight Muslim states at that time voted in favor of the UDHR. ${ }^{111}$ Only Saudi Arabia abstained from signing the UDHR. ${ }^{112}$ Thus, Muslim countries such as Afghanistan, Iran and Iraq, which were critiqued by the International Commission on Religious Freedom, were in the UN at the time of ratification, and all voted in favor of the UDHR. ${ }^{113}$

The second major treaty that impacts worldwide religious freedom is the ICCP. ${ }^{114}$ The treaty is the "'only global human rights treaty dealing with religion that contains measures of implementation.",115 Article 18 of the treaty in part states:

Everyone shall have the right to freedom of thought, conscience and religion. This right shall include freedom to have or to adopt a religion or belief of his choice, and freedom, either individually or in community with others and in public or private, to manifest his religion or belief in worship, observance, practice and teaching. ${ }^{116}$

108. G.A. Res. 217(III)A, supra note 103, at 74.

109. Id. at 72 .

110. Louis B. Sohn, The New International Law: Protection of the Rights of Individuals Rather than States, 32 AM. U. L. REV. 1, 15 (1982) ("[T]he General Assembly, after some amendments, approved it unanimously, with eight abstentions: the Soviet bloc, Saudi Arabia, and the Union of South Africa.").

111. Carolyn Ratner, Book Note, Islamic Laws as Violations of Human Rights in the Sudan, 18 B.C. THIRD WORLD L.J. 137, 148-49 (1998) (reviewing JUdiTH MILLER, GOD HAS NinETYNine NAMES (1996)).

112. Id. Saudi Arabia objected to the phrasing of Article 18 involving freedom of religion and refused to sign. Michael Ignatieff, Human Rights as Idolatry, in HUMAN RIGHTS AS POLITICS AND IDOLATRY 53, 58-59 (Amy Gutmann ed., 2001).

113. OfFICE OF THE High COMM'R FOR Human Rights, THE UNIVERSAL DEClARATION OF HUMAN Rights: A MAGNA CARTA FOR ALL HUMANITY, http://www.unhchr.ch/udhr/miscinfo/ carta.htm (Dec. 1997) (DPI/1937/A) (on file with the Duke Law Journal).

114. G.A. Res. supra note 104, at 55.

115. Gordon Smith, Protecting the Weak: Religious Liberty in the Twenty-First Century, 1999 BYU L. REV. 479, 480 (quoting Natan Lerner, Religious Human Rights Under the United Nations, in Religious Human Rights in Global Perspective: Legal Perspectives 79, 98 (Johan D. van der Vyver \& John Witte, Jr. eds., 1996)).

116. G.A. Res. supra note 104, at 55. 
Other parts of the ICCP also have articles that mirror the intent of IRFA. Article 27 focuses on the rights of minorities and maintains that "[i]n those States in which ethnic, religious or linguistic minorities exist, persons belonging to such minorities shall not be denied the right, in community with the other members of their group, to enjoy their own culture, to profess and practice their own religion, or to use their own language." ${ }^{117}$ Muslim countries such as Iran, Iraq, Afghanistan, Egypt, Libya, Morocco, and Sudan, have all ratified the treaty. ${ }^{118}$ Together, the UDHR and the ICCP form the core of the protection of international religious freedom. ${ }^{119}$

IRFA is the primary means that the United States employs to ensure that the religious freedom treaties are enforced. As the international documents and treaties illustrate, IRFA is designed to remind other countries that they must support the UDHR or the ICCP. As articulated by one of the drafters of IRFA, Steve Moffitt:

One hundred and five nations are members of the United Nations. They all signed up to [the UN Charter] and to the Universal Declaration of Human Rights. So when other countries say it's a United States bill, we say no, your government signed up to this and we're simply asking you to adhere to something you signed onto. If you don't mean it, then get your name off it, but your name is on there. ${ }^{120}$

\section{B. IRFA Supports the Freedom of Religion as a Universal Right}

Proponents of human rights believe that certain, basic rights are universal. Human rights are "'human' because they are implied in humanity. They cannot be transferred, waived, forfeited, usurped, or lost through failure to exercise them." ${ }^{121}$ As an integral part of human rights, religious freedom is a universal value that extends to all people. As former Ambassador Robert Seiple has stated: "You can't

117. Id. at 56 .

118. Manfred NowaK, U.N. Covenant on Civil and Political Rights: CCPR COMMENTARY app. at 886-89 (1993).

119. See Natan Lerner, The Nature and Minimum Standards of Freedom of Religion or Belief, 2000 BYU L. REV. 905, 931 ("Article 18 of the Universal Declaration and Article 18 of the 1966 Covenant on Political and Civil Rights are the basic provisions in the global instruments addressing religious freedom.").

120. Religious Persecution As a U.S. Policy Issue: Proceedings OF A Consultation Held at Trinity College, Hartford 16 (Rosalind I.J. Hackett et al. eds., 2000).

121. Catherine Powell, Introduction: Locating Culture, Identity, and Human Rights, 30 COLUM. HuM. RTS. L. REV. 201, 202 (1999). 
have an idea of human rights as universal, and then argue against them on the basis of domestic internal issues .... Human rights transcends nation states." curring in countries like Sudan involve "the severest forms of crimes against humanity, violations of so-called jus cogens under international law." ${ }^{123}$ By seeking to advance religious freedom, IRFA is ensuring that a basic right of every human is recognized and protected.

The universality of religious freedom is proven by the identity of the people who clamor to have that freedom protected. "Human rights has gone global by going local, empowering the powerless, giving voice to the voiceless." ${ }^{, 124}$ As one scholar notes, "while government or religious elites may object on cultural grounds to human rights norms as 'Western,' individual citizens within these cultures are oftentimes the voices asserting these very norms." 125 For example, when Muslims were persecuted in Bosnia and prevented from practicing their religion, they did not need to read Locke, Mill, or Jefferson, ${ }^{126}$ to know that what they were experiencing was a violation of a fundamental right. As one would expect with all humans suffering persecution, those persecuted in Bosnia sought a "Bosnia in which everybody [would] pray to God the way their mothers taught them, in which nobody [would] be persecuted for their religion, nation or political beliefs." ${ }^{27}$ Similarly, a man suffering in Sudan pled, "I am therefore appealing to you ... to help us in our struggle for survival and faith." ${ }^{128}$ This response to persecution is a basic human response that is as

122. Witham, supra note 22, at A2.

123. Adams, supra note 17, at 5. The Vienna Convention on the Law of Treaties defines "jus cogens" as a principle that is "accepted and recognized by the international community of States as a whole as a norm from which no derogation is permitted." Vienna Convention on the Law of Treaties, May 23, 1969, art. 53, 1155 U.N.T.S. 331.

124. Michael Ignatieff, Human Rights as Idolatry, in HumAn RIGHTS AS POLITICS AND IDOLATRY 53, 70 (Amy Gutmann ed., 2001).

125. Powell, supra note 121, at 210-11.

126. See Michaël Fischer, Note, The Human Rights Implications of a "Cultural Defense”, $6 \mathrm{~S}$. CAL. INTERDISC. L.J. 663, 691-92 (1998) (footnote omitted):

The term "human rights" is a modern name for the natural rights or natural law philosophies that were postulated by such thinkers as Locke, Mill, and Jefferson in the seventeenth and eighteenth centuries. These philosophers based their ideas on the general notion that all people, through nothing more than being a member of the human family, have certain universal rights to decent treatment.

127. Bosnia's President Votes in Landmark Elections, AGENCE Fr.-PRESSE, Sept. 14, 1996.

128. Crimes Against Humanity in Sudan: Joint Hearing Before the Subcomm. on Int'l Operations and Human Rights and the Subcomm. on Africa of the Comm. on Int'l Relations of the House Comm. on Int'l Relations, 106th Cong. 93 (1999) (statement of Mark T. Ajo, Sudanese Church Worker). 
natural of a response as the cries from a baby that is hungry. Thus, by recognizing religious freedom as a universal right, a country respects the most essential of "human" values. This implies "that there are certain fundamental rights that no government in the world may violate." ${ }^{129}$

A final means to respond to the charge that human rights are Western values is to find parallels in Muslim thought. Most recently, human rights scholars, seeking to foster human rights in Muslim countries, have argued that the Qur'an has most of the human rights principles in it. For example, one scholar has claimed that "it is indeed the reverse of the truth for Western jurists to suggest that there was no doctrine of human rights in Islamic jurisprudence." ${ }^{130}$ Another has argued, that the Qur'an

is the Magna Carta of human rights and that a large part of its concern is to free human beings from the bondage of traditionalism, authoritarianism (religious, political, economic, or any other), tribalism, racism, sexism, slavery or anything else that prohibits or inhibits human beings from actualizing the [Qur'anic] vision of human destiny embodied in the classic proclamation: "Towards Allah is thy limit" .... ${ }^{131}$

Still another scholar has concluded that the Qur'an "posits, or contains evidence for, a kind of universal guidance which, in its availability to all humanity seems parallel to the Western-Christian idea of a natural moral law." ${ }^{, 132}$ Nonetheless, other scholars have questioned whether the Qur'an can reasonably be used to argue for or against human rights. One has stated that like the Bible, the Qur'an "is a vast, vague book, filled with poetry and contradictions .... You can find in it condemnations of war and incitements to struggle, beautiful expressions of tolerance and stern strictures against unbelievers. Quotations

129. Wiktor Osiatyński, Human Rights for the 21st Century, 2000 ST. LOUIS-WARSAW TRANSATLANTIC L.J. 29, 40.

130. C.G. WEERAMANTRY, ISLAMIC JURISPRUDENCE 126-27 (1988), quoted in HUMAN RIGHTS IN ISLAMIC LAW iii (Tahir Mahmood ed., 1993). Mahmood also quotes Mohammed, "O mankind! the Arab is not superior to non-Arab, nor vice versa; the white has no superiority over the black, nor vice versa; and the rich has no superiority over the poor. All of you are Adam's descendants and Adam was made of earth," and notes that "[t] he most fundamental right of man ... was ... proclaimed as the credo of the Islamic religion by its Prophet himself." Tahir Mahmood, The Islamic Law on Human Rights, in HUMAN RIGHTS IN ISLAMIC LAW, supra, at 33.

131. Riffat Hassan, Religious Human Rights and the Qu'ran, 10 EMORY INT'L L. REV. 85, 85 (1996).

132. LitTLE ET AL., supra note 96, at 91. 
from it usually tell us more about the person who selected the passages than about Islam.,"133

\section{IRFA Does Not Forbid the Union of Church and State}

Critics have failed to understand what IRFA is attempting to accomplish. IRFA is not attempting to have other countries adopt the First Amendment as their own. As explained by one of the members of the Commission, the "law does not seek to give U.S. law extraterritorial effect." ${ }^{, 134}$ Instead, IRFA seeks to foster a minimum level of religious tolerance. Aligned with this precept, IRFA allows a country to favor established religions. The State Department's 2001 Report states: "International covenants allow legal restrictions on religious practice, but they must be applied scrupulously and fairly, in as limited a way as possible, without discriminating among religions." ${ }^{135}$ IRFA's provisions allow countries to support the establishment of a special religion within a country due to its historical status in the country. ${ }^{136}$ For example, countries that have religious establishments ${ }^{137}$ that receive no critique from IRFA's investigative bodies include: Norway and its Lutheran state church, the United Kingdom and its Anglican church, Greece and its Greek Orthodox church, and Malta and its Roman Catholic Church. Similarly, for Israel, the State Department Report did not criticize Israel for being a "Jewish state" but

\footnotetext{
133. Zakaria, supra note 55, at 22 .

134. Hatch, supra note 33, at 419.

135. U.S. DEP'T OF STATE, supra note 49, at xv (emphasis added).

136. Western society has long accepted the union of church and state. See Guy Haarscher, Freedom of Religion in Context, 2002 BYU L. REV. 269, 272-73 (footnotes omitted):

For instance, in Germany no real separation of the domains of the churches and federated entities ... exists. Likewise in Greece, the dominant Orthodox Church intervenes in many aspects of secular life. The Anglican Church is stricto sensu established in England with the queen at its head although no real advantages exist for the faithful of the dominant denomination. Finally, in Denmark, the Lutheran religion is the official practice....
}

Similarly, it was only as recently as Vatican II in 1965 that the Catholic Church recognized the idea of religious freedom when it issued the Declaration of Religious Liberty and Declaration on the Revelations of the Church to Non-Christian Religions. JOHN T. NOONAN, JR. \& EDWARD MCGLYNN GAFFNEY, JR., Religious FreEDOM 685-86 (2001). Thus, though Muslim doctrine may require a more extreme connection with church and state, the western world has embraced this principle as well.

137. David M. Smolin, Exporting the First Amendment?: Evangelism, Proselytism, and the International Religious Freedom Act, 31 CUMB. L. REV. 685, 688-89 (2001). 
for discriminating against Arabs. ${ }^{138}$ The "mere existence of a state church or officially-sanctioned or favored religion does not of itself violate any norm of international law." 139 Accordingly, IRFA does not attempt to restrict the predominance of Islam in Muslim societies.

\section{IRFA Recognizes That Religion May Be a Pretext for Persecution}

The world's history is full of atrocities committed under a religious pretext. Just as the Confederacy relied on the Bible to justify slavery, ${ }^{140}$ so too could the Qur'an be abused. The drafters of IRFA recognized the possibility of using religion as a pretext for persecution. The Report states: "[T]radition and culture should not be used as a pretext for laws or policies that restrict genuine religious belief or its legitimate manifestation." ${ }^{141}$ With this concern, some human rights activists have challenged whether some Muslim countries are using the Qur'an as a pretext to torment minority populations. ${ }^{142}$

The Qur'an seems to offer instructions on how to treat minority faiths that seems to conflict with how some Muslim persecutors are acting. The Qur'an states: "Let there be no compulsion / In religion ...." ${ }^{143}$ Some Muslim scholars have interpreted this to mean that Muslims "cannot persuade anyone to accept Islam by moral, social or

138. U.S. DEP'T OF STATE, supra note 49, at 444 ("Israeli Arabs are subject to various forms of discrimination, some of which have religious dimensions. Israeli Arabs and other non-Jewish Israelis, are, in fact, generally free to practice their religions.").

139. Smolin, supra note 137, at 689.

140. Paul Finkelman, The Centrality of the Peculiar Institution in American Legal Development, 68 CHI.-KENT L. REV. 1009, 1028 (1993) (noting that an "elaborate biblical justification of slavery [was] articulated by armies of Southern ministers [and that] Southerners accepted the argument, which comforted them with the knowledge that their behavior was sanctioned by God" (citation omitted)).

141. U.S. DEP'T OF STATE, supra note 49, at xv.

142. See, e.g., Grant Garrard Beckwith, Note \& Comment, Uzbekistan: Islam, Communism, and Religious Liberty-An Appraisal of Uzbekistan's 1998 Law "On Freedom of Conscience and Religious Organizations," 2000 BYU L. REV. 997, 1003 (explaining how authorities in Uzbekistan are "using religion as a pretext for political persecution and control"). The pretext argument is an admittedly delicate argument because it forces one into the intricate and uncomfortable world of adjudging the "sincerity" of religious beliefs. However, this does not mean the "pretext" argument must be ceded entirely because religion undeniably has been and will continue to be used as a pretext for evil acts. Although there may be no role for the U.S. State Department telling Muslims what the Qur'an "really requires," scholars of human rights, law, and theology can play an important role in addressing the "pretext" issue.

143. QUR'AN 2:256. 
political pressure." ${ }^{144}$ Other parts of the Qur'an also preach religious tolerance:

... O ye / That reject Faith! / I worship not that / Which ye worship, / Nor will ye worship / That which I worship. / And I will not worship / That which ye have been / Wont to worship / Nor will ye worship / That which I worship. / To you be your Way, / And to me mine. ${ }^{145}$

Accordingly, these verses imply that the persecution of religious minorities may potentially lack clear theological grounding. Of course, other parts of the Qur'an and Islamic law apparently do support some of the acts of persecution. For example, there is theological support for the belief that apostasy warrants the death penalty. Despite "the absence of any specific text in the Qur'an sanctioning the death penalty for apostasy," ${ }^{, 146}$ parts of the Qur'an can reasonably be interpreted to condemn apostasy. ${ }^{147}$

The Qur'an seems to contain somewhat conflicting messages on religious freedom. On one hand, it mandates tolerance; on the other hand, it supports the death penalty for apostasy. However, in reviewing the "penal law of Islam it becomes evident that with the exception of apostasy, no legal penalties are provided for offences against religion as such; they will be dealt with in the hereafter." ${ }^{148}$ If the Qur'an lacks clarity on the matter of religious freedom, or has passages that undermine support for religious oppression altogether, the persecutor's argument that he must oppress others to fulfill his religious obligations is undeniably weakened, and the acts seem more likely to be in the realm of religious pretext. Notably, most of the acts of persecutions occurring in the Muslim world do not involve apostasy. ${ }^{149}$ Instead, they involve general animus against minorities, based arguably more on prejudice than theology. These acts may, in fact, oppose the Qur'an's “no compulsion” principle. Accordingly, if the

144. Sheikh Showkat Husain, Human Rights in Islam: Principles and Precedents, in HUMAN RIGHTS IN ISLAMIC LAW, supra note 130, at 96.

145. QUR'AN 109:1-6.

146. LITTLE ET AL., supra note 96, at 80.

147. See Tad Stahnke, Proselytism and the Freedom to Change Religion in International Human Rights Law, 1999 BYU L. REV. 251, 281-82 (detailing the revolt of the tribes after Mohammed's death as the source for the long held Muslim belief in the evils of apostasy).

148. LITTLE ET AL., supra note 96, at 78.

149. The slavery in the Sudan, the detentions in Turkmenistan, the murders in Iran, the campaign against the Shi'a in Iraq, and the banning of all non-Muslim practices in Saudi Arabia detailed in Part II do not directly relate to the problem of apostasy but instead involve general discrimination against other faiths or sects. 
acts of persecution are based on a religious pretext, the accusations of imperialism have far less credibility, and the United States should have fewer reservations about condemning these acts.

\section{RECTIFYING IRFA's FLAWS}

IRFA has merit, but, as implemented, it has flaws that needlessly augment a critic's argument for why it is an act of imperialism. To minimize these flaws, the United States must change how it approaches international religious freedom through IRFA.

\section{A. Reduce Christian-Centric Biases}

The United States must protect all religions equally. One flaw of IRFA that reinforces the imperialist accusations against it is that, in both its enactment and its implementation, the United States has focused too much on protecting Christians suffering religious persecution and has not done enough to protect other religious minorities facing persecution. ${ }^{150}$ One defender of IRFA concedes that "IRFA can be criticized in practice for focusing disproportionately on religious issues of particular concern to Americans." reinforced by the fact that many of the early supporters of IRFA were reacting against persecutions of Christians. ${ }^{152}$ Various conservative Christian groups such as the Southern Baptists, the National Association of Evangelicals, and the Family Research Council rallied to support IRFA ${ }^{153}$ initially because they were outraged that Christians were being denied the right to evangelize in other countries. ArabAmerican and American Muslim opposition to IRFA "was based on the concern that the bills were not part of a serious effort to provide balanced protections to the rights of religious minorities. Rather, they saw clear signs of ideological bias in the rhetoric of the legislation's advocates."154

150. See Gunn, supra note 25 , at 854 (conceding that there has been "a relatively greater awareness of difficulties encountered by Protestant Evangelical, Catholic, and Jewish communities abroad than, for example, the problems encountered by Muslims and Orthodox Christians").

151. Id.

152. See McCormick, supra note 36, at 283-84 (recognizing that there was tremendous political attention from Christian as well as Jewish groups).

153. Gunn, supra note 25, at 852-53.

154. James J. Zog, A Partial View of Religious Rights and Wrongs, Gulf News (U.A.E.), May 7, 2000. 
How IRFA has been implemented has also had a slightly Christian bias. For example, though the war in Sudan is truly a horrible religious war, it is not the horror of the war alone that has garnered it the attention of the State Department and the Commission. The fact that victims who were being slaughtered were Christian also played a large role in the U.S. response: "The war in Sudan is, in part, a religious one. That helps explain why conservative Christian groups were among the first to call for stronger U.S. action." 155 Joe Stork, advocacy director for the Middle East division of Human Rights Watch, has noted that most of the cases in which the United States intervened diplomatically on behalf of religious minorities in the Middle East tended to "involve sort of Christian situations." ${ }^{156}$ In implementing IRFA, the Commission, the State Department, and the president must ensure that they act with equal resolve no matter which religious sect is being persecuted.

\section{B. Self-Assess the United States}

IRFA should include a self-assessment of the United States. Though IRFA's mandate extends to every other country in the world (194 countries), neither the State Department nor the Commission can do a self-assessment of the status of religious freedom within U.S. borders. ${ }^{157}$ This failure supports the claim that the United States believes it is superior to the rest of the world on human rights values. As one scholar has analyzed, "[t]he universality of human rights is threatened by a superpower that treats human rights as a paradigm that applies 'over there' but not 'here." "158 Former Ambassador Seiple has criticized the United States for its failure to do a self-assessment: "At the very least, this presents the potential for hubris, arrogance, and hypocrisy. It suggests an inclination to report only on others, refraining from any sort of self-criticism."159

\footnotetext{
155. Steve Hirsch, Why Sudan Matters, NAT'L J. 1640, 1642 (2001). Some Muslims have also expressed concern that the war in Sudan is being used to depict Islam in a negative light. Teresa Watanabe, Sudan's Abuse of Religious Freedom Assailed, L.A. TimES, May 13, 2000, at B6 ("Many Muslims ... suspect that the egregious plight of Sudan-one of Africa's poorest countries pummeled by nearly four decades of civil war-is being exploited by some Christians to vilify Islam.").

156. John Lancaster, State's Witness for the Persecution; Ambassador Robert Seiple Takes on Cause of Global Religious Freedom, WASH. POST, Nov. 30, 1999, at A27.

157. Seiple, supra note 28, at 99.

158. Powell, supra note 121, at 224.

159. Seiple, supra note 28 , at 99.
} 
In evaluating the status of the United States's religious freedom, a special rapporteur to the UN quoted an unnamed academic: "Congress thinks we do just fine on religious liberty issues, and the rest of the world should not be telling us how to get it right." ${ }^{160}$ However, the rapporteur did find some areas of concern, and particularly highlighted the plight of Native Americans:

The Native Americans are without any doubt the community facing the most problematical situation, one inherited from a past of denial of their religious identity, in particular through a policy of assimilation, which most Native Americans insist on calling genocide (physical liquidation, religious conversion, attempts to destroy their traditional way of life, laying waste of land, etc.). ${ }^{161}$

A thorough self-assessment of the United States through IRFA would be useful as a means to evaluate the validity of such a troubling critique.

\section{Support International Frameworks}

Supporters of IRFA should also support other Human Rights initiatives. One claim that has given IRFA's critics considerable ammunition with which to attack it is the extent to which IRFA's supporters have failed to fully recognize and support the existing international treaties established to combat human rights in general. ${ }^{162}$ Ironically, IRFA's strongest conservative supporters are the same people who also often advocate isolation from the UN. For example, some of the champions of IRFA were the same people who supported the United States's refusal to pay UN dues. ${ }^{163}$ One human rights scholar has critiqued that "[i]t is curious that the U.S. is so protective of its own sovereignty that it refuses to ratify an almost univer-

160. Abdelfattah Amor, Visit to the United States of America, U.N. ESCOR, Comm'n on Human Rights, 55th Sess., Addendum II 28, U.N. Doc. E/CN.4/1999/58/Add.1 (1999).

161. Id. at 53 .

162. See Little, supra note 68 , at 610 (querying whether the right to freedom of religion deserves special status over other human rights).

163. See Charles Tiefer, Adjusting Sovereignty: Contemporary Congressional-Executive Controversies About International Organizations, 35 TEX. INT'L L.J. 239, 252 (2000) (explaining the reasons why some Republicans were in favor of withholding UN dues). For example, Representative Gerald B.H. Solomon and Senator Rod Grams supported the United States's refusal to pay UN dues. George Archibald, Irked Lawmakers Hit Albright's Lack of "Domestic Diplomacy," WASH. TIMES, April 4, 1998, at A4. Both of these individuals voted for IRFA because as noted earlier, IRFA "was passed unanimously by both houses of Congress." Seiple, supra note 28 , at 98 . 
sally ratified treaty like the Rights of the Child Convention, and yet it expects other countries to share its own particular concern with freedom of religion." 164 Former White House National Security Advisor Samuel Berger maintained that "the more the United States is perceived as making unilateral, preemptory judgments on the performance of other countries, the less we will be able to work with those countries-including on issues of religious freedom." ${ }^{165}$

Supporting religious freedom "requires the enforcement of rights against murder, torture, enslavement, and the whole host of other human rights that weave together into a fabric of protection essential to clothe human life with dignity." "Some critics of IRFA have charged that by enacting IRFA, the United States has created a "hierarchy of human rights." ${ }^{167}$ By legislating this hierarchy through IRFA, "the United States runs counter to the principle of indivisibility of rights found in customary law." 168 Others have noted that "prioritizing religious persecution over other human-rights abuses may unfairly allocate resources in such a way as to discriminate against those persecuted for other reasons." ${ }^{169}$ When the United States fails to support other UN initiatives on human rights, its efforts to foster religious freedom are more likely to fail.

\section{Do Not Sacrifice Religious Freedom for Political Purposes}

One final problem with IRFA is that the State Department and the president have been too flexible in regard to how they respond when countries violate religious freedom. The State Department's "report details a number of countries where conditions have deteriorated, but U.S. policy has not responded." ${ }^{, 70}$ The United States sanc-

164. Religious PerseCUtion AS A U.S. POLICY IsSUe, supra note 120, at 25-26 (remarks of Prof. Abdullahi Ahmed An-Na'im, Emory University School of Law).

165. Religious-Persecution Bill Passes in House, 115 CHRISTIAN CENTURY 569, 569 (1998).

166. Little, supra note 68, at 610.

167. Kristin N. Wuerffel, Note, Discriminating Among Rights?: A Nation's Legislating a Hierarchy of Human Rights in the Context of International Human Rights Customary Law, 33 VAL. U. L. REV. 369, 396 (1998):

By creating an office to monitor religious persecution, establishing a Commission and a position in the National Security Council, and specifically providing for action to be taken in response to states' violations of religious freedom, the Act distinguishes among human rights. In so doing, it establishes a hierarchy of human rights within U.S. law.

168. Id. at 412.

169. Sullivan, supra note 10, at 10-11.

170. Elliott Abrams, Editorial, Candle in the Darkness: Religious Freedom is a Foreign Policy Beacon, WASH. TIMES, Jan. 1, 2001, at A15. 
tions rogue states like Iraq, but allows allies like Saudi Arabia to go untouched, even though the IRFA Report states: "Saudi Arabia is an Islamic monarchy without legal protection for freedom of religion, and such protection does not exist in practice."171

The result is that "[d]ifferential application of sanctions measures has lead critics to contend that U.S. sanctions policies, far from being motivated by respect for international norms, simply reflect the whims and fads of U.S. domestic politics." ${ }^{\text {172 }}$ Recently, the United States has particularly refused to act against countries that are allies in its war against terrorism. Human Rights Watch noted that the State Department's Report "candidly described violations of religious freedom around the world, but failed to designate Uzbekistan, Saudi Arabia, and Turkmenistan as 'Countries of Particular Concern.",173 However, "[b]y not designating Uzbekistan a 'Country of Particular Concern,' the administration missed an easy opportunity to show that the war on terrorism cannot be a campaign against Islam., ${ }^{174}$ It also missed an opportunity to prove to Muslim countries that IRFA is not an imperialist tool of American foreign policy designed only to protect American interests. By not being willing to sanction equal violators with equal punishments, the United States delegitimizes its argument that the freedom of religion is absolute and inalienable. To trade religious freedom in exchange for political security, like mere trinkets or baubles, is to minimize the claim for its universality.

\section{CONCLUSION}

The United States must find a means to carry the banner for religious freedom in a way that distinguishes it from the imperial ban-

171. U.S. DEP'T OF STATE, supra note 49, at 477.

172. Sarah H. Cleveland, Norm Internalization and U.S. Economic Sanctions, 26 YALE J. INT'L L. 1, 75 (2001).

173. Press Release, Human Rights Watch, supra note 95.

174. Id.; see also Christopher H. Smith, Focused on Terror, U.S. Cannot Lose Sight of Religious Liberty, INSIGHT ON THE NEWS, Dec. 24, 2001, at 46, 46:

Apparently unbeknownst to policymakers, promoting religious freedom can achieve the goal of concretely communicating the administration's intention to make war against terror and not Islam. For example, the [State Department's Annual Report on International Religious Freedom] clearly cites Uzbekistan's “abuses against many devout Muslims for their religious beliefs." During the last three years, thousands of nonviolent Muslims have been imprisoned for merely worshiping at unapproved mosques.

Supporting religious liberty in countries may also play a direct role in creating an environment in which terrorists flourish. See supra Part I. 
ner carried by conquerors, crusaders, and conquistadors. The United States cannot allow the catastrophic abuses of religious freedom occurring throughout the world to continue without censure. Approximately half the world lives without religious liberty ${ }^{175}$ and in the twentieth century, twenty-seven million people have died for reasons related to their faith. ${ }^{176}$ For too long, the United States has neglected this vital area. Now, in the post-September 11 world, where religion and politics intersect all the more, the United States has even more incentives to focus on the world's calamitous problem of religious freedom. Although the United States should certainly ruminate on any imperialistic tendencies of its actions, it should not hesitate to act in this critical area. As former Ambassador Seiple has stated: "People have to insist that humanitarian intervention on this issue is just as important at some level as what we do with our military security or economic contracts." ${ }^{177}$ Though the United States must act, it must act wisely. The flaws in the implementation of IRFA must be rectified because Muslims will justifiably "weigh your God and you" and assess whether the United States is imperialistically asserting American concepts of religion onto Muslim countries. Some of IRFA's flaws unnecessarily erode the United States's valid claim that religious freedom is a universal freedom, and the flaws provide support for critics' accusations of imperialism. Once the recommended changes are made in how IRFA is implemented, the law has the potential to be a useful tool for the United States to accomplish its goals of fostering worldwide religious freedom without marching down the sinister path of imperialism.

175. 22 U.S.C. $\$ 6401(a)(4)(2000)$.

176. Starr, supra note 41, at 988.

177. Religious Freedom and U.S. Policy: An Interview with Robert Seiple, 116 CHRISTIAN Century 419, 421 (1999). 